1 Title: How do parole board members in England and Wales construct decisions about

2 whether to release perpetrators of intimate partner violence from prison?

3

4 1. Abstract

5

6 Background

7 Existing research explores Parole Board decision-making, but not specifically for perpetrators

8 of Intimate Partner Violence (IPV), a special case due to the gendered and secretive nature of

$9 \quad$ IPV and the role of control in predicting reoffending.

10

11 Aim

12 To identify associations between case variables in England and Wales Parole Board decisions regarding perpetrators of IPV and explore how these variables help construct the decision.

15 Methods

16 Logistic regressions regarding decisions in a sample of all 137 male prisoners who had

17 abused women and applied for release or progression to open conditions in England and

18 Wales from April 2018 to September 2019, developed into latent class analyses.

19 Thematic analyses of 6 interviews with Parole Board members about decision-making in IPV 20 cases.

21

\title{
22 Results
}

23 Release decisions were strongly predicted by the recommendations of Offender Managers,

24 Offender Supervisors and Psychologists, mediated by the Parole Board's confidence in their 25 ability. Decisions were also significantly associated with custodial behaviour and attendance 
26 on courses, mediated by the Board's confidence in the prisoner's insight and honesty.

27 Thematic analysis was both consistent with these findings and provided a context in which 28 the associations could be understood.

29

30 Conclusions

31 The findings have implications for understanding the dynamic between professional decisions

32 and the Parole Board's decision; for the importance of Offender Managers demonstrating

33 their expertise and ability to manage risk; for Parole Board members' reflection and

34 development; for academic research into IPV; and for those who have experienced IPV and 35 are looking to understand parole decisions about their abuser.

36

37 Key words:

38 Parole Board decisions; decision-making; intimate partner violence; heuristics; systems 39 thinking 40 


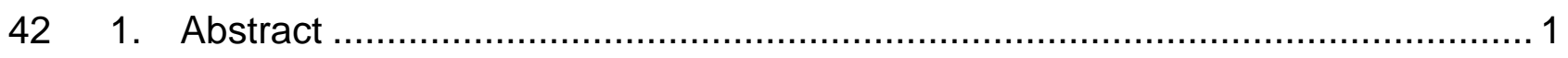

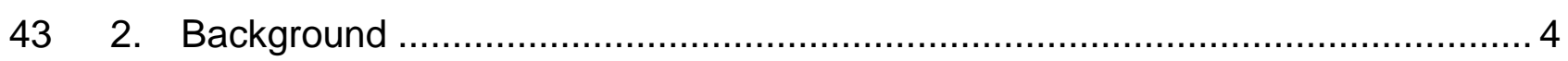

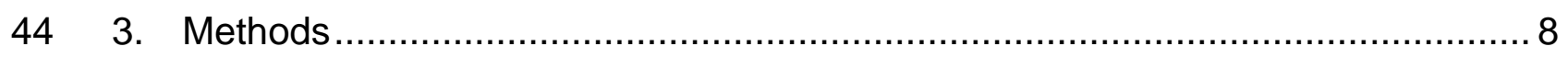

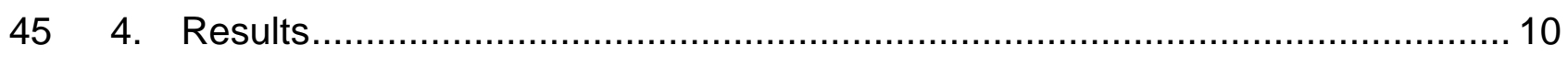

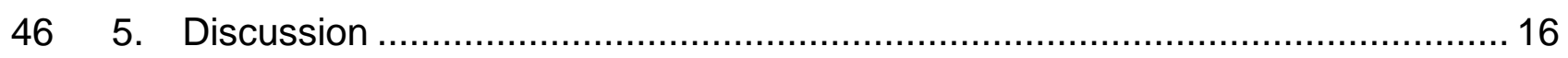

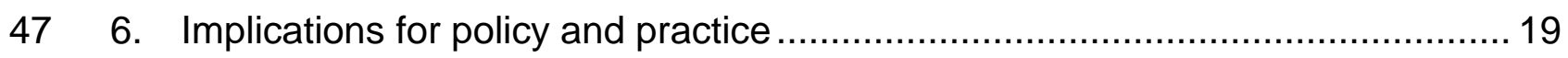

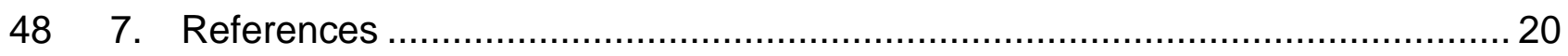

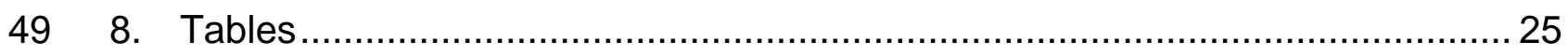

50 


\section{How general parole decisions are made}

55 The term 'parole' comes from the French for 'word of honour', but parole decisions today

56 require much more than the prisoner's word.

57 The Parole Board in England and Wales decides whether to: direct a prisoner's release; recommend that they progress from 'closed' to 'open' prison (allowing them more time in the community); or direct that they remain in prison until a further statutory review or their remaining term, whichever is shorter. The Board must be "satisfied that it is no longer necessary for the protection of the public that [the prisoner] be confined" (Parole Board, 2019) in order to direct release or recommend progression. They are assisted by a dossier containing relevant reports from professionals including: the Offender Supervisor (OS) who oversees the offender's time in prison; the Offender Manager (OM) responsible for the risk management plan after release; Psychologists; and coordinators of relevant programmes.

66

67 Existing research has identified factors associated with general parole decisions, and how these are constructed within a wider system of case-specific and external influences. The factors can include prisoner characteristics such as their age and 'parole readiness' (Huebner \& Bynum, 2006), mental health (Caplan, 2010; Shingler \& Needs, 2018, although Houser et al., 2019, found minimal impact) and substance misuse (Bradford \& Cowell, 2012). Other relevant factors include the prisoner's offending: the severity of the index offence (Caplan, 2010; Huebner \& Bynum, 2006; Tzeng, 2014) and patterns of offending (Caplan, 2010); and

74 their subsequent time in prison: their 'institutional behaviour' (Caplan, 2010; Connor, 2016;

75 Huebner \& Bynum, 2006) including whether they have completed perpetrator programmes 76 (Connor, 2016). The perceived effectiveness of the risk management plan is also an important 77 consideration (Bradford \& Cowell, 2012), reflecting Padfield's (2017) emphasis on the 'luck' 
78 of having high-quality Offender Managers and a Parole Board willing to "take a chance" on

79 their plan. Decision-makers are also wary of 'impression management' among violent

80 offenders (Mills \& Kroner, 2006) and sex offenders (Cochran \& Comeau-Kirschner, 2016).

81 Overall, therefore, the parole decision involves an understanding of internal protections

82 against reoffending: 'habit-based compliance' and 'normative compliance' based on moral

83 values, as well as how reoffending is prevented by external incentives ('instrumental

84 compliance') and coercion ('constraint-based compliance') (Bottoms, 2001).

85 However, these factors have not been studied in the specific case of Intimate Partner

86 Violence (IPV), and more qualitative and quantitative research is needed to test these

87 associations (Padfield, 2017). The current mixed methods study explores how Parole Boards

88 in England and Wales make decisions about parole for a man imprisoned for IPV against a

89 female partner or ex-partner. These decisions warrant attention due to how the nature of IPV

90 offences predicts reoffending, and the gendered and secretive nature of most IPV.

91 This research considers the tensions decision-makers experience in these contexts: between

92 the broader legal framework and the minutiae of individual cases; and between public safety

93 and the right of the individual to fair treatment and the chance to reform (Kohler-Hausmann,

94 2019).

95

96 The complexity of decision-making in criminal justice

97 A decision to release is not only determined by a set of case characteristics.

98 Social psychological research on the relationship between internal and external factors

99 affecting a decision-maker (Hancock et al., 2018; Rothstein et al., 2006) includes the

100 interaction between conscious and unconscious decision-making (Greene \& Dalke, 2020;

101 Soon et al., 2008), and the role of 'heuristics' or mental short-cuts (Fiedler \& Sydow, 2015) 
102

103

104

105

106

107

108

109

110

111

112

113

114

115

116

117

118

119

120

121

122

123

124

125

126

as applied to decisions in the courts (Dhami \& Belton, 2017) and criminal justice more broadly (Peer \& Gamliel, 2013).

The mechanisms through which Parole Board members reach decisions are further complicated by the 'risk society' (Kemshall, 2019) and 'risk colonisation' (Rothstein et al., 2006). This involves the pressure to reduce organisational risk - i.e. blame for a prisoner reoffending after release, such as in the Hanson or Rice cases (Harding, 2006) - being conflated or confused with the aim to reduce societal risk, which includes balancing different risks of societal harm.

\section{Special considerations regarding Intimate Partner Violence decisions}

Research on parole decisions about perpetrators of IPV is limited, and complicated by the nature of IPV, which is arguably highly gendered (Anderson \& Umberson, 2001; Johnson, 2006; Kimmel, 2002; Razera et al., 2017), occurs in private (creating greater uncertainty for decision-makers), and overlaps numerous different offences. While the Government's recent introduction of the offence of 'coercion and control' (Myhill \& Hohl, 2016) is specific to IPV, other relevant offences including murder, rape, assault and false imprisonment are not, though this is partly mitigated by the creation of a statutory definition of domestic abuse in the current Domestic Abuse Bill (Parliament, 2020).

Domestic Violence Perpetrator Programmes (DVPPs) seek to reduce reoffending, and have been linked to an increased likelihood of a release decision (Connor, 2016). However, while individual trials suggest reduced abusive behaviour following attendance (Doyle et al., 2018; Kelly \& Westmarland, 2015; Strang et al., 2017), wider systematic studies have not identified a significant difference in reoffending between abusers who have, and have not, attended courses (Babcock et al., 2004; Gondolf, 2011; Haggård et al., 2017; Vigurs et al., 2016). 
127 Further understanding of the role of DVPPs in release decisions is therefore needed, given the

128 lack of evidence for their effectiveness.

129 The 'nature' of IPV can predict future offending (Goldstein et al., 2016; Kingsnorth, 2006),

130 considered in this research in terms of: the Composite Abuse Scale (Hegarty et al., 2005)

131 which identified 'Severe Combined Abuse' as more dangerous to the survivor's welfare than

132 physical, emotional, sexual abuse or harassment alone; and Johnson's (2006) typology that

133 distinguished 'Intimate Terrorism', involving an element of control over the victim, from

134 'Situational Couple Violence' which lacks unilateral control. Intimate terrorism, victim-

135 blaming and minimisation correlate with self-reported repeat offending (Lila et al., 2008;

136 Scott \& Straus, 2007), while control, power, jealousy and misogyny/patriarchal beliefs are all

137 found more commonly in clinical samples than general population IPV (Love et al., 2018).

138 Within the DASH (Richards, 2009) model of risk, the following variables predicted future

139 offending: prior violent history; alcohol and drug abuse; recent separation; and a victim's

140 level of fear of their abuser (Almond et al., 2017).

141

142 This research fills gaps in two areas of the research:

143 1) which factors are most strongly associated, in England and Wales, with a Parole

144 Board decision to release a perpetrator of IPV (or progress them to open conditions),

145 and whether these factors overlap with those associated with IPV reoffending or

$146 \quad$ parole decisions more widely;

147 2) how these factors affect decisions: whether parole board members are conscious of all

148 the factors that influence their decisions, and why they place weight on specific

149 factors. 
152 To explore associations between factors and decisions and the dynamics behind any

153 associations, this research includes quantitative and qualitative elements.

154 The cases include a range of crimes against a current or former intimate partner. The study

155 includes decisions about offenders on indeterminate, life and determinate sentences, either for 156 initial release or for release after recall.

157 This article reports midway findings from a project that received ethical approval from the 158 UCL Institute of Education Ethics Committee in October 2018 (no. Z6364106/2018/07/78), 159 and from the Parole Board's Research Governance Group in May 2019.

160 The lead researcher is a male $\mathrm{PhD}$ student, - a point for reflection given the gendered nature 161 of the topic - a former social worker and expert witness with several years' experience of IPV cases in the criminal and family courts, providing background insights but also creating the 163 possibility of bias from prior assumptions about the topic.

\section{The Quantitative Element}

167 The analysis used 137 decision letters representing each eligible parole hearing from April 2018 to September 2019 that involved male perpetrators and female victims in open or closed prisons (after excluding 5 cases involving female/transgender perpetrators and/or male/transgender victims, or where the offender was in a psychiatric institution).

172 The variables were recoded into binary versions, allowing logistic regressions between each

173 candidate variable and the decision to release the prisoner (or progress them to open

174 conditions), and latent class analyses to identify groups of cases, before conducting further 175 logistic regressions between membership of those latent classes and the decision. 
177 The Qualitative Element

178

179 Interviews were conducted from August to November 2019, with 20 Parole Board members

180 recruited through an appeal via the Parole Board Policy and Research Lead. This self-

181 selecting convenience sample (from the population of 246 members), comprised 8 former

182 probation officers, 3 members with backgrounds working with IPV cases, 4 psychologists, 2

183 judges and 3 lay members. Interviewees received a consent form, information sheet and the

184 topic guide in advance.

185 Six interview transcripts were selected at random for analysis, and double-coded by authors

186 independently as the first stage of an inductive-deductive-recursive cycle (Rubin \& Rubin,

187 2011) in which data were recoded as themes emerged (including the quantitative analysis

188 themes). 


\section{Quantitative Data: Logistic Regressions}

192

193 Logistic regressions identified 17 factors (see Table 1$)$ significantly associated $(\mathrm{p}<0.05)$ with 194 a decision to release an offender or progress them to open conditions. Of particular note were 195 the associations between professional recommendations and decisions: prisoners were much more likely to be released if their Offender Supervisor, Psychologist and/or Offender

197 Manager recommended it. Other factors strongly associated with a decision to release or 198 progress a prisoner included the Parole Board's impression of personal factors such as the 199 prisoner's honesty, insight, positive attendance on DVPPs, and working relationships with 200 professionals. There were also statistically significant associations between a 201 release/progression decision and 'structural' factors such as the effectiveness of the risk 202 management plan, the imminence of risk (more so than the level of risk) and the offender's 203 links in the community.

204

205 [table 1 here]

206

207 Collinearity testing identified no redundancy: no two variables had a Variance Inflation 208 Factor (VIF) greater than 7.5, short of the suggested cut-off for redundancy of 10 (O'Brien, 209 2007).

210

211 Quantitative data: latent class analyses of significant factors 212 
213 Latent class analysis of the 'professional input' categories (see Table 2) showed a significant 214 association between the recommendations of the OM, OS and psychologist, and the Board's 215 decision.

216

217 [table 2 here]

218

219 Only 1 of 45 prisoners were released/progressed where professional opinion opposed it, 220 compared to 77 out of 90 prisoners where professionals mostly supported release 221 professional recommendations therefore seemed to be a necessary condition for release, 222 although not always sufficient. This was made clearer in a three-class model, which split the 223 latter class into two: one where 64 of 65 were released, and another intermediate class where 224 only about half (13 of 25) were released. This smaller category was distinguished by higher 225 levels of perceived risk and by lower confidence in the effectiveness of the risk management 226 plan, despite professional support for release.

227 In other words, Parole Boards were inclined to release/progress prisoners on the

228 recommendation of professionals, provided they had confidence in those professionals' 229 expertise and their ability to manage the risk.

230 Further latent class analyses identified best-fit models for those factors associated with the 231 prisoner's 'journey' from offending to the hearing (Table 3) and with the prisoner's life after 232 release (Table 4). Both sets of categories were significantly associated with different 233 likelihoods of release, though accounting for less variance in outcome than the "professional 234 input' model (Table 2).

236 [table 3 here] 
[table 4 here]

239

240 Qualitative data: thematic analysis of interviews

241

242 Initial coding from 6 transcripts produced 5 overarching themes as follows:

243

\section{The Parole Board member within the decision}

245 Interviewees reflected on how their decision-making was influenced (consciously and

246 subconsciously) by their backgrounds - "we see the world through the prisms of our past

247 experiences" (Interviewee \#02) - and by the tensions between personal feelings, their

248 theoretical knowledge, and the legal tests: "occasionally something just gets under your skin, 249 and you can't legislate for it happening” (Interviewee \#03)

250

\section{Offender journey}

252 Interviewees discussed how they considered the path the offender has followed: from

253 previous patterns of offending and the index offence, through their experience of prison, and

254 the evidence for change. This included exploring the role of controlling behaviour in previous

255 offences, and the degree to which the offender showed remorse and took responsibility for 256 their actions.

257 They considered the tension between real and apparent change: "whether they've taken 258 responsibility of their offending... tangible evidence that they've shifted in attitudes" 259 (Interviewee \#04) or "whether he just paid lip service" (Interviewee \#01).

260 Interviewees were not impressed by attendance on courses (DVPPs), but by its effects, e.g. 261 "whether you can see evidence that the [DVPP]'s made any difference to how the person 262 talks about things" (Interviewee \#03). 


\section{Looking ahead to life after release}

265 All the interviewees said they considered the quality of risk management plans post-release and the prisoner's overall circumstances, i.e. "what are they coming out to?” (Interviewee \#01). They considered the offender's age; social/community resources; behaviour in the community, how much time has elapsed; and their relationships with their community and potential partners.

They were not only concerned with the presence of a factor but the nuanced role it played: for

271 example, whether their close-knit family could be said to be "protective" or just "supportive"

272 (Interviewee \#05); or whether a close relationship with professionals suggested an

273 encouraging degree of compliance, or a concerning degree of dependence that lacked what

274 Bottoms (2001) called 'habit-based' or 'normative' compliance. They emphasised the

275 manageability and "imminence of risk" (Interviewee \#01): whether the risk is easily

276 identified in advance and whether the offender can self-manage or be trusted to disclose

277 problems. For example: “you're more likely to take a punt on release if you're confident that

278 the risk management plan is 'on it' and ready to recall if necessary" (Interviewee \#04).

279

\section{Confidence in other professionals}

281 Interviewees described shifting levels of confidence, scepticism and trust in experts such as

282 psychologists and OMs and how their evidence stands up to scrutiny. For example, there

283 were cases where "a panel wonders whether the OM would be strong enough when being

284 challenged" (Interview \#4). Further, there appeared to be a wariness of release

285 recommendations where professionals place more weight on an offender's custodial

286 compliance than future risk, e.g. "[they're] well behaved in prison, very compliant, so you'll

287 get the OM and OS saying 'release them' because they're looking at current behaviour' 
288 (Interviewee \#5). They also described the need for confidence in probation officer's ability to 289 create and implement an effective risk management plan, and the tension between consistency and integrity - they found similar conclusions encouraging unless one expert's

291 conclusions were simply adopted uncritically by others. In this sense, interviewees

292 consistently perceived that the psychologist tended to be given "an exalted role of 293 importance” (Interviewee \#1)

\section{Environmental pressures in the hearing and beyond}

296 The hearing structure itself plays a role, with interviewees usually feeling less risk-averse

297 when meeting an offender than when reading the relevant information. For example:

298 'I'd never accept releasing on the papers... there have been many, many times when I've 299 changed my mind after hearing from the prisoner" (Interviewee \#01)

300 "more often than not [the prisoner's presence] makes release a bit more likely" (Interviewee $301 \# 04)$.

302 Interviewees also acknowledged external influences: pressures to release (especially for IPPs) 303 but also pressure from media/public against release (particularly after high-profile cases such as Worboys). They argued: “it's really nuanced decision-making, which can be hard to convey and explain" outside the hearing (Interviewee \#04).

They identified dissonance between the legal and substantive impacts of information where

307 they were legally prohibited from including something in their deliberations but were still 308 aware of it, e.g. the inclusion of a victim impact statement - "if I'm hearing that, you can't not be affected" (Interviewee \#04) or the involvement of children: "it shouldn't legally make any difference to our job" (Interviewee \#02) yet “you can't 'un-know' things that are in a

311 dossier" (Interviewee 04). 
313 These five overarching themes converged with the quantitative associations, as explored 314 further in the next section. 
318 This study helps to identify factors associated with a decision to release IPV perpetrators, and

319 to shed some light on the mechanisms by which these factors lead to a decision. The recommendations of the OS, OM and psychologist were the strongest predictors, especially

321 when the recommendation was against release/progression.

322 The association between recommendations and decisions could also reflect a tendency for

323 decision-makers to absorb assumptions from previous decision-makers (Peer \& Gamliel, 324 2013), or even the "chumminess" bemoaned by Padfield (2017). There was the risk that the psychologist's report may become reified, and unduly influence the OM and OS (who read the report before giving their own recommendations) - a perception shared by prisoners

327 (Shingler \& Needs, 2018). Alternatively, the association may reflect that the OM, OS and 328 psychologist are influenced by the same factors as the Parole Board.

Our finding that prisoners who had completed DVPPs with 'positive' or 'neutral' feedback were 5.3 times more likely to be released (see Table 1) than those who had not (either

332 through non-attendance or unsatisfactory attendance) was consistent with prior research

333 (Connor, 2016). However, both the latent class analysis and thematic analysis suggested that offenders with good custodial behaviour and attendance on courses were much less likely to be released if they did not also impress the Board with their insight and honesty.

337 The results were also consistent with previous findings (Caplan, 2010; Huebner \& Bynum, 338 2006; Tzeng, 2014) identifying associations between the nature and severity of the offence(s)

339 and the Parole Board's decision. However, this association did not relate to the type of 340 offence but to the nature of IPV involved, using Johnson's (2006) distinction between 
341 offenders who exert control over their victims ('intimate terrorism') and those whose

342 behaviour is chaotic and not involving control ('situational couple violence'). The latter

343 group were over 6 times more likely to be released than the former (see Table 1). This

344 reflects interviewees' perceptions that someone whose violence is linked to visible risk

345 factors (e.g. alcohol and drug misuse, unstable mental health, disengagement from networks)

346 can be more easily recalled before becoming violent, compared to someone with a controlling

347 personality.

348

349 However, the quantitative data did not reflect the consistent emphasis by interviewees, or the

350 findings of previous research (Almond et al., 2017; Caplan, 2010) on previous IPV offending

351 or substance abuse. While offenders with no prior offending or substance misuse were more

352 likely to be released, the difference was not statistically significant for the current sample

353 size.

354

355 Offenders were much more likely to be released if they were serving indeterminate or life

356 sentences and had served a longer sentence, but the latent class with the highest chances of

357 release were those who also had robust risk management plans, a good record of behaviour in

358 the community and broadly positive community networks in place. The interviewees

359 consistently emphasised risk manageability rather than risk level, consistent with the relative

360 effect sizes of these factors (and the significance of the quality of risk management plans) in

361 the logistic analyses.

362 This is not only consistent with broader findings around the importance of 'parole readiness'

363 (Huebner \& Bynum, 2006) and the risk management plan (Bradford \& Cowell, 2012) but

364 resembles the 'willingness to take a chance' identified as a more random variable by Padfield 
365 (2017). These findings suggest that what seems like a 'punt' based on the offender's characteristics may be driven by the reassurance provided by the quality of the OM's plan.

\section{Strengths and Limitations of the research}

369 The analysis, like the research itself, is provisional: the finished project will involve a larger

370 quantitative dataset (by extending the timeframe earlier than April 2018) where these

371 conclusions can be tested, and further rounds of thematic coding and analysis across all 20

372 interview transcripts. There are gaps in the research: it does not allow firm conclusions about

373 the causal direction underpinning these associations since it only considers each case as a

374 'snapshot' after the hearing has concluded; and it does not analyse the significance of the

375 prisoner's ethnicity or whether they have children (neither of which were routinely included 376 in the decision letters).

377 Further research could use a longitudinal approach to unpick the causal direction of some of

378 these associations, exploring in more depth whether individual views form in parallel, one-

379 after-the-other, or through their interaction in the hearing.

380 However, the research demonstrates the feasibility of a mixed-methods design for a subset of 381 parole decisions, while producing statistically significant results despite the smaller sample. It

382 also allows discussion of convergent themes across different types of data (we found no

383 divergences) and the focus on decisions about male perpetrators of IPV in England and Wales

384 is novel.

385 Ultimately, the research contributes to the field by demonstrating significant correlations 386 between key aspects of a case (most significantly, the recommendations of other

387 professionals) and the Parole Board's decision, at the same time as providing a qualitative 388 context in which these associations can be better understood. 
6. Implications for policy and practice

391 This research extends the study of parole decision-making to the special case of IPV

392 offenders. The findings support previous research around the influence of professionals on a 393 decision-making process, and overlap with research on parole decisions across all offenders 394 (custodial behaviour, attending programmes, honesty) and with research on factors that predict IPV: the prisoner's insight and the absence of controlling behaviour.

396

397 The findings have implications for the recommendations of the Offender Manager, Offender

398 Supervisor and especially the Psychologist, and whether these exercise a de facto 'veto' over 399 a prisoner's release: while Parole Boards can release a prisoner over professional objections, 400 in practice they very rarely do. Arguably this could amount to an informal dynamic where, 401 effectively, prisoners must first secure professional recommendations for release/progression 402 before seeking the Parole Board's final approval.

403 The findings have implications for Offender Managers: whether the Board accepts their 404 recommendations is closely linked to their perceived expertise and ability to manage the 405 offender's risk.

406

407 The findings are useful for academic research into IPV offenders, for the future training of 408 criminal justice professionals, and for Parole Board members' reflection and development.

409 They also have implications for people who have experienced IPV who seek deeper 410 understanding of why a perpetrator was, or was not, released: for example, how perpetrators 411 of intimate terrorism are less likely to be released, and how attendance on programmes and 412 other 'lip service' is insufficient to secure release. 
Almond, L., McManus, M., Brian, D., \& Merrington, D. P. (2017). Exploration of the risk factors contained within the UK's existing domestic abuse risk assessment tool (DASH): Do these risk factors have individual predictive validity regarding recidivism? Journal of Aggression, Conflict and Peace Research, 9(1), 58-68. https://doi.org/10.1108/JACPR-01-2016-0211

Anderson, K. L., \& Umberson, D. (2001). Gendering violence: Masculinity and power in 422 men's accounts of domestic violence. Gender \& Society, 15(3), 358-380.

Bottoms, A. (2001). Community Penalties: Change and Challenges. Taylor \& Francis.

Bradford, S., \& Cowell, P. (2012). The decision-making process at parole reviews (indeterminate imprisonment for public protection sentences). 10.

Caplan, J. M. (2010). Parole Release Decisions: Impact of Positive and Negative Victim and Nonvictim Input on a Representative Sample of Parole-Eligible Inmates. Violence and Victims, 25(2), 224-242. https://doi.org/10.1891/0886-6708.25.2.224

Cochran, E. P., \& Comeau-Kirschner, C. (2016). The language of parole: Sex offenders' discourse strategy use in Indeterminate Sentence Review Board hearings. WORD, 62(4), 244-267. https://doi.org/10.1080/00437956.2016.1248669

Connor, D. P. (2016). How to Get Out of Prison: Views from Parole Board Members. Corrections, 1(2), 107-126. https://doi.org/10.1080/23774657.2015.1125767

Dhami, M. K., \& Belton, I. K. (2017). On getting inside the judge's mind. Translational 435 Issues in Psychological Science, 3(2), 214-226. https://doi.org/10.1037/tps0000115

Doyle, K., Levtov, R. G., Barker, G., Bastian, G. G., Bingenheimer, J. B., Kazimbaya, S., Nzabonimpa, A., Pulerwitz, J., Sayinzoga, F., Sharma, V., \& Shattuck, D. (2018). Gender-transformative Bandebereho couples' intervention to promote male engagement in reproductive and maternal health and violence prevention in Rwanda: 
Findings from a randomized controlled trial. PLOS ONE, 13(4), e0192756. https://doi.org/10.1371/journal.pone.0192756

442 Fiedler, K., \& Sydow, M. von. (2015). Heuristics and biases: Beyond Tversky and Kahneman 's ( 1974 ) judgment under uncertainty.

444 Goldstein, D. A., Cantos, A. L., Brenner, L. H., Verborg, R. J., \& Kosson, D. S. (2016). Perpetrator Type Moderates the Relationship Between Severity of Intimate Partner Violence and Recidivism. Criminal Justice and Behavior, 43(7), 879-898. https://doi.org/10.1177/0093854815616841

Greene, J., \& Dalke, I. (2020). "You're still an angry man”: Parole boards and logics of criminalized masculinity. Theoretical Criminology, 1362480620910222. https://doi.org/10.1177/1362480620910222

Hancock, K., Brown, P., Hadgis, A., Hollander, M., \& Shrider, M. (2018). Parole Board Personality and Decision Making Using Bias-Based Reasoning. In D. D. Schmorrow \& C. M. Fidopiastis (Eds.), Augmented Cognition: Users and Contexts (pp. 255-272). Springer International Publishing. https://doi.org/10.1007/978-3-319-91467-1_21

Harding, J. (2006). Some reflections on risk assessment, parole and recall. Probation Journal, 53(4), 389-396. https://doi.org/10.1177/0264550506069363

Hegarty, K., Bush, R., \& Sheehan, M. (2005). The Composite Abuse Scale: Further

Houser, K. A., Vîlcică, E. R., Saum, C. A., \& Hiller, M. L. (2019). Mental Health Risk Factors and Parole Decisions: Does Inmate Mental Health Status Affect Who Gets Released. International Journal of Environmental Research and Public Health, 16(16), 2950. https://doi.org/10.3390/ijerph16162950 
465

466

467

468

469

470

471

472

473

474

475

476

477

478

479

480

481

482

483

484

485

486

487

Huebner, B. M., \& Bynum, T. S. (2006). An Analysis of Parole Decision Making Using a Sample of Sex Offenders: A Focal Concerns Perspective*. Criminology, 44(4), 961991. https://doi.org/10.1111/j.1745-9125.2006.00069.x

Johnson, M. P. (2006). Conflict and control: Gender symmetry and asymmetry in domestic violence. Violence against Women, 12(11), 1003-1018.

Kelly, L., \& Westmarland, N. (2015). Domestic violence perpetrator programmes: Steps towards change. Project Mirabal final report.

Kemshall, H. (2019). Risk in Probation Practice. Routledge.

Kimmel, M. S. (2002). "Gender Symmetry” in Domestic Violence: A Substantive and Methodological Research Review. Violence Against Women, 8(11), 1332-1363. https://doi.org/10.1177/107780102237407

Kingsnorth, R. (2006). Intimate Partner Violence: Predictors of Recidivism in a Sample of Arrestees. Violence Against Women, 12(10), 917-935.

https://doi.org/10.1177/1077801206293081

Kohler-Hausmann, I. (2019). Malcolm Feeley's Concept of Law (pp. 36-54). https://doi.org/10.1017/9781108234979.003

Lila, M., Herrero, J., \& Gracia, E. (2008). Evaluating Attribution of Responsibility and Minimization by Male Batterers: Implications for Batterer Programs. The Open Criminology Journal, 1(1). https://benthamopen.com/ABSTRACT/TOCRIJ-1-4

Love, H. A., Spencer, C. M., May, S. A., Mendez, M., \& Stith, S. M. (2018). Perpetrator Risk Markers for Intimate Terrorism and Situational Couple Violence: A Meta-Analysis. Trauma, Violence, \& Abuse, 1524838018801331.

https://doi.org/10.1177/1524838018801331 
488

489

490

491

492

493

494

495

496

497

498

499

500

501

502

503

504

505

506

507

508

509

510

511

Mills, J. F., \& Kroner, D. G. (2006). Impression Management and Self-Report Among Violent Offenders. Journal of Interpersonal Violence, 21(2), 178-192. https://doi.org/10.1177/0886260505282288

Myhill, A., \& Hohl, K. (2016). The "Golden Thread": Coercive Control and Risk Assessment for Domestic Violence. Journal of Interpersonal Violence, 0886260516675464. https://doi.org/10.1177/0886260516675464

O’brien, R. M. (2007). A Caution Regarding Rules of Thumb for Variance Inflation Factors. Quality \& Quantity, 41(5), 673-690. https://doi.org/10.1007/s11135-006-9018-6

Padfield, N. (2017). Parole Board Oral Hearings 2016-2017 - Exploring the Barriers to Release: Stage Two of an Exploratory Study (SSRN Scholarly Paper ID 3081039). Social Science Research Network. https://doi.org/10.2139/ssrn.3081039

Domestic Abuse Bill 2020, HL Bill 124, Parliament, House of Commons, 2019-2020 (2020). https://publications.parliament.uk/pa/bills/lbill/58-01/124/5801124_en_1.html

Parole Board. (2019). The Parole Board Decision-Making Framework. 28.

Peer, E., \& Gamliel, E. (2013). Heuristics and Biases in Judicial Decisions. Court Review, 49, $114-119$.

Razera, J., Gaspodini, I. B., Falcke, D., Razera, J., Gaspodini, I. B., \& Falcke, D. (2017). Intimate Partner Violence and Gender A/Symmetry: An Integrative Literature Review. Psico-USF, 22(3), 401-412. https://doi.org/10.1590/1413-82712017220302

Richards, L. (2009). Domestic abuse, stalking and harassment and honour based violence (DASH, 2009) risk identification and assessment and management model.

Rothstein, H., Huber, M., \& Gaskell, G. (2006). A theory of risk colonization: The spiralling regulatory logics of societal and institutional risk. Economy and Society, 35(1), 91112. 
512 Rubin, H. J., \& Rubin, I. S. (2011). Qualitative Interviewing: The Art of Hearing Data.

513

514 Scott, K., \& Straus, M. (2007). Denial, Minimization, Partner Blaming, and Intimate

515

516

517

518

519

520

521

522

523

524

525

526

527

528

529

530

531

532

533

534

Aggression in Dating Partners. Journal of Interpersonal Violence, 22(7), 851-871. https://doi.org/10.1177/0886260507301227

Shingler, J., \& Needs, A. (2018). The role of psychological risk assessment in Parole Board decision making: An exploration of the perspectives of psychologists, indeterminate sentenced prisoners and Parole Board members. Prison Service Journal, 237, 36-40.

Soon, C. S., Brass, M., Heinze, H.-J., \& Haynes, J.-D. (2008). Unconscious determinants of free decisions in the human brain. Nature Neuroscience, 11(5), 543-545. https://doi.org/10.1038/nn.2112

Strang, H., Sherman, L., Ariel, B., Chilton, S., Braddock, R., Rowlinson, T., Cornelius, N., Jarman, R., \& Weinborn, C. (2017). Reducing the harm of intimate partner violence: Randomized controlled trial of the Hampshire Constabulary CARA Experiment. Cambridge Journal of Evidence-Based Policing, 1(2-3), 160-173.

Tzeng, S. (2014). Applying DEMATEL to Investigate the Relationship Between Factors Affecting Parole Boards’ Decision-Making in Taiwan. The Prison Journal, 94(1), 118-136. https://doi.org/10.1177/0032885513512096

Weiss, B. A., \& Dardick, W. (2016). An Entropy-Based Measure for Assessing Fuzziness in Logistic Regression. Educational and Psychological Measurement, 76(6), 986-1004. https://doi.org/10.1177/0013164415623820 
537 Table 1: Factors associated with a decision to release or progress an offender

\begin{tabular}{|c|c|c|c|c|c|}
\hline Factor & $\begin{array}{l}\text { Released / } \\
\text { progressed } \\
\text { when present }\end{array}$ & $\begin{array}{l}\text { Released / } \\
\text { progressed } \\
\text { when } \\
\text { absent }\end{array}$ & $\begin{array}{l}\text { Odds } \\
\text { ratio }\end{array}$ & $\mathrm{p}$ & $\begin{array}{l}\text { Nagelkerke } \\
\mathrm{R}^{2} \\
\text { (highest } \\
\text { first) }\end{array}$ \\
\hline $\begin{array}{l}\text { Offender Supervisor } \\
\text { supports } \\
\text { release/progression }\end{array}$ & 71 of 81 & 1 of 37 & 255.5 & $<0.001$ & 0.713 \\
\hline $\begin{array}{l}\text { Psychologist supports } \\
\text { release/progression }\end{array}$ & 32 of 40 & 0 of 20 & $\mathrm{n} / \mathrm{a}$ & $\mathrm{n} / \mathrm{a}$ & 0.682 \\
\hline $\begin{array}{l}\text { Offender Manager supports } \\
\text { release/progression }\end{array}$ & 71 of 82 & 3 of 47 & 94.6 & $<0.001$ & 0.670 \\
\hline Positive honesty/openness & 27 of 28 & 17 of 53 & 57.2 & $<0.001$ & 0.485 \\
\hline $\begin{array}{l}\text { 'Robust, effective' risk } \\
\text { management plan } \\
\text { (compared to cases with } \\
\text { concerns about the plan) } *\end{array}$ & 65 of 71 & 6 of 21 & 27.1 & $<0.001$ & 0.453 \\
\hline $\begin{array}{l}\text { Positive insight/remorse } \\
\text { into offence (compared to } \\
\text { 'lack of insight/remorse') }\end{array}$ & 31 of 34 & 8 of 35 & 34.5 & $<0.001$ & 0.426 \\
\hline $\begin{array}{l}\text { Positive insight/remorse } \\
\text { into offences and behaviour } \\
\text { (compared to 'mixed' } \\
\text { insight/remorse) }\end{array}$ & 31 of 34 & 14 of 26 & 8.8 & 0.003 & 0.426 \\
\hline $\begin{array}{l}\text { Good working relationship } \\
\text { with professionals }\end{array}$ & 56 of 79 & 3 of 26 & 18.7 & $<0.001$ & 0.334 \\
\hline $\begin{array}{l}\text { 'Medium' or 'low' } \\
\text { imminence of harm** }\end{array}$ & 65 of 90 & 8 of 37 & 9.4 & $<0.001$ & 0.268 \\
\hline $\begin{array}{l}\text { 'Protective' social and } \\
\text { community links } \\
\text { (compared to 'mixed' or } \\
\text { 'concerning' links) }\end{array}$ & 22 of 26 & 17 of 41 & 7.8 & 0.001 & 0.239 \\
\hline $\begin{array}{l}\text { Indeterminate / life } \\
\text { sentence (rather than } \\
\text { determinate sentence) }\end{array}$ & 58 of 80 & 17 of 56 & 6.0 & $<0.001$ & 0.218 \\
\hline $\begin{array}{l}\text { Completed perpetrator } \\
\text { programme with positive or } \\
\text { neutral feedback }\end{array}$ & 49 of 65 & 26 of 71 & 5.3 & $<0.001$ & 0.194 \\
\hline $\begin{array}{l}\text { Coded as Situational } \\
\text { Couple Violence (rather } \\
\text { than Intimate Terrorism) }\end{array}$ & 28 of 33 & 45 of 100 & 6.8 & $<0.001$ & 0.164 \\
\hline $\begin{array}{l}\text { Positive or mixed reports } \\
\text { from community releases } \\
\text { (rather than serious }\end{array}$ & 30 of 39 & 20 of 48 & 4.7 & 0.01 & 0.164 \\
\hline
\end{tabular}




\begin{tabular}{|c|c|c|c|c|c|}
\hline $\begin{array}{l}\text { concerns about community } \\
\text { behaviour) }\end{array}$ & & & & & \\
\hline $\begin{array}{l}\text { 'Model prisoner' or only } \\
\text { minor arbitrations in } \\
\text { custody }\end{array}$ & 60 of 87 & 11 of 36 & 5.1 & $<0.001$ & 0.159 \\
\hline $\begin{array}{l}\text { Each year elapsed since } \\
\text { offence }\end{array}$ & $\mathrm{n} / \mathrm{a}$ & $\mathrm{n} / \mathrm{a}$ & 1.1 & 0.01 & 0.125 \\
\hline $\begin{array}{l}\text { 'Medium' or 'low' risk of } \\
\text { harm to future partner** }\end{array}$ & 20 of 25 & 54 of 105 & 3.8 & 0.013 & 0.073 \\
\hline $\begin{array}{l}\text { Open prison (rather than } \\
\text { closed estate) }\end{array}$ & 13 of 15 & 57 of 105 & 5.5 & 0.030 & 0.070 \\
\hline Non-significant factors: & & & & & \\
\hline $\begin{array}{l}\text { Lacking problematic or } \\
\text { addictive substance use }\end{array}$ & 6 of 7 & 45 of 84 & 5.2 & 0.135 & 0.044 \\
\hline Offender did not kill victim & 53 of 104 & 22 of 32 & 0.5 & 0.080 & 0.031 \\
\hline No prior IPV convictions & 40 of 64 & 35 of 71 & 1.7 & 0.124 & 0.023 \\
\hline $\begin{array}{l}\text { Not coded as Severe } \\
\text { Combined Abuse (Hegarty) }\end{array}$ & 35 of 56 & 40 of 80 & 1.7 & 0.150 & 0.020 \\
\hline Victim statement provided & 17 of 25 & 58 of 111 & 1.9 & 0.157 & 0.020 \\
\hline Decision made on papers & O of 14 & 50 of 86 & $n / a$ & $n / a$ & 0.020 \\
\hline 3-person panel $* * *$ & 31 of 50 & 18 of 36 & 1.6 & 0.269 & 0.019 \\
\hline $\begin{array}{l}\text { Offender did not sexually } \\
\text { abuse victim }\end{array}$ & 61 of 106 & 14 of 30 & 1.5 & 0.292 & 0.011 \\
\hline $\begin{array}{l}\text { No prior violent } \\
\text { convictions }\end{array}$ & 11 of 24 & 64 of 111 & 0.6 & 0.293 & 0.011 \\
\hline $\begin{array}{l}\text { Each additional year of } \\
\text { age }\end{array}$ & $n / a$ & $n / a$ & 1.0 & 0.440 & 0.011 \\
\hline $\begin{array}{l}\text { Each year remaining on } \\
\text { sentence }\end{array}$ & $n / a$ & $n / a$ & 1.1 & 0.580 & 0.008 \\
\hline $\begin{array}{l}\text { Psychologist on the } \\
\text { panel }^{* * *}\end{array}$ & 18 of 35 & 57 of 101 & 1.2 & 0.231 & 0.000 \\
\hline Judge on the panel $* * *$ & 9 of 15 & 66 of 121 & 1.2 & 0.231 & 0.000 \\
\hline $\begin{array}{l}\text { Acknowledging offence } \\
\text { (rather than denial) }\end{array}$ & 74 of 122 & 6 of 20 & 1.3 & 0.132 & 0.000 \\
\hline $\begin{array}{l}\text { No concerns re: suspected } \\
\text { manipulation }\end{array}$ & 73 of 121 & 7 of 21 & 1.3 & 0.132 & 0.000 \\
\hline
\end{tabular}


543 Table 2: latent classes based on professional input

\begin{tabular}{|c|c|c|c|c|}
\hline \multirow{2}{*}{\multicolumn{2}{|c|}{ Latent Class }} & \multicolumn{2}{|c|}{ "Recommended for Release" } & \multirow{2}{*}{$\begin{array}{l}\text { "Opposed to } \\
\text { Release" }\end{array}$} \\
\hline & & $\begin{array}{c}\text { "Highly } \\
\text { Recommended" }\end{array}$ & $\begin{array}{c}\text { "Risky but } \\
\text { Recommended" }\end{array}$ & \\
\hline \multicolumn{2}{|c|}{ Effective risk management plan } & $94.9 \%$ & $68 \%$ & $38.3 \%$ \\
\hline \multicolumn{2}{|c|}{$\begin{array}{l}\text { Offender Manager recommended } \\
\text { release/progression }\end{array}$} & $100 \%$ & $82.6 \%$ & $4.9 \%$ \\
\hline \multicolumn{2}{|c|}{$\begin{array}{l}\text { Offender Supervisor } \\
\text { recommended release/progression }\end{array}$} & $100 \%$ & $100 \%$ & $0 \%$ \\
\hline \multicolumn{2}{|c|}{$\begin{array}{l}\text { Psychologist recommended } \\
\text { release/progression }\end{array}$} & $100 \%$ & $100 \%$ & $4.8 \%$ \\
\hline \multicolumn{2}{|c|}{ Medium/Low level of harm* } & $40.5 \%$ & $0 \%$ & $9.8 \%$ \\
\hline \multicolumn{2}{|c|}{ Medium/Low imminence of harm* } & $95.8 \%$ & $63.9 \%$ & $46.5 \%$ \\
\hline \multirow{2}{*}{$\begin{array}{l}\text { 3-class } \\
\text { model }\end{array}$} & Released / progressed & 64 of 65 & 13 of 25 & 1 of 45 \\
\hline & $\begin{array}{l}\text { Odds ratio of } \\
\text { release/progression } \\
\text { relative to "Opposed" } \\
\text { group }\left(\mathrm{R}^{2}=0.774\right)\end{array}$ & $\begin{array}{c}894.7 \\
p<0.001\end{array}$ & $\begin{array}{c}47.6 \\
p<0.001\end{array}$ & $\mathrm{n} / \mathrm{a}$ \\
\hline \multirow[t]{2}{*}{ 2-class } & Released / progressed & \multicolumn{2}{|c|}{77 of 90} & 1 of 45 \\
\hline & $\begin{array}{l}\text { Odds ratio of } \\
\text { release/progression } \\
\text { relative to "Opposed" } \\
\text { group }\left(\mathrm{R}^{2}=0.673\right)\end{array}$ & \multicolumn{2}{|c|}{$\begin{array}{c}217.1 \\
\mathrm{p}<0.001\end{array}$} & $\mathrm{n} / \mathrm{a}$ \\
\hline
\end{tabular}

544 3-class model: Bayesian Information Criterion $(\mathrm{BIC})=655$; Entropy $=0.775$ 'moderate'

545 (Weiss \& Dardick, 2016)

546 2-class model: $\mathrm{BIC}=644$; Entropy=0.94, 'high'

$547 *$ : various measures used 
549 Table 3: latent classes based on the prisoner's 'journey' and reflections on offending

\begin{tabular}{|c|c|c|c|}
\hline Class & 'Resistant' & 'Lip Service' & 'Engaging' \\
\hline $\begin{array}{l}\text { 'Situational Couple } \\
\text { Violence' rather than } \\
\text { 'Intimate Terrorism' } \\
\text { (Johnson 2006) }\end{array}$ & $0 \%$ & $23.1 \%$ & $38.6 \%$ \\
\hline $\begin{array}{l}\text { Completed perpetrator } \\
\text { programme } \\
\text { satisfactorily }\end{array}$ & $8.9 \%$ & $38.7 \%$ & $75.8 \%$ \\
\hline $\begin{array}{l}\text { 'Model prisoner' or } \\
\text { only minor } \\
\text { arbitrations in custody }\end{array}$ & $24.9 \%$ & $61.8 \%$ & $96.8 \%$ \\
\hline $\begin{array}{l}\text { Working well with } \\
\text { professionals }\end{array}$ & $0 \%$ & $85.3 \%$ & $100 \%$ \\
\hline $\begin{array}{l}\text { Positive } \\
\text { honesty/openness }\end{array}$ & $7 \%$ & $0 \%$ & $83.3 \%$ \\
\hline $\begin{array}{l}\text { Positive } \\
\text { insight/remorse }\end{array}$ & $\begin{array}{c}0 \% \text { good } \\
0 \% \text { mixed } \\
100 \% \\
\text { problematic }\end{array}$ & $\begin{array}{c}0 \% \text { good } \\
52.2 \% \text { mixed } \\
47.8 \% \\
\text { problematic }\end{array}$ & $\begin{array}{c}86.7 \% \text { good } \\
13.3 \% \text { mixed } \\
0 \% \text { problematic }\end{array}$ \\
\hline Released / progressed & 2 of 25 & 30 of 65 & 43 of 49 \\
\hline $\begin{array}{l}\text { Odds ratio of } \\
\text { release/progression } \\
\text { relative to 'Resistant' } \\
\text { offenders } \\
\left(\mathrm{R}^{2}=0.423\right)\end{array}$ & $\mathrm{n} / \mathrm{a}$ & $\begin{array}{c}10 \\
p<0.001\end{array}$ & $\begin{array}{c}90.9 \\
P<0.001\end{array}$ \\
\hline
\end{tabular}


553 Table 4: latent classes for 'looking ahead' to the offender's life after release

\begin{tabular}{|c|c|c|c|c|}
\hline Class & $\begin{array}{l}\text { 'Recent } \\
\text { unstable' }\end{array}$ & 'Unstable' & $\begin{array}{l}\text { 'Historic, } \\
\text { settling' }\end{array}$ & 'Stable' \\
\hline $\begin{array}{l}\text { Years elapsed since } \\
\text { index offence } \\
(\text { mean) }\end{array}$ & 4.2 & 11.3 & 21.8 & 13.6 \\
\hline $\begin{array}{l}\text { Indeterminate or } \\
\text { life sentences } \\
\text { (rather than } \\
\text { determinate) }\end{array}$ & $13.2 \%$ & $82.3 \%$ & $100 \%$ & $100 \%$ \\
\hline $\begin{array}{l}\text { Good or mixed } \\
\text { behaviour on } \\
\text { community } \\
\text { releases (rather } \\
\text { than problematic) }\end{array}$ & $31.2 \%$ & $24 \%$ & $49.7 \%$ & $100 \%$ \\
\hline $\begin{array}{l}\text { Effective risk } \\
\text { management plan }\end{array}$ & $66.7 \%$ & $59.1 \%$ & $100 \%$ & $100 \%$ \\
\hline $\begin{array}{l}\text { Protective social } \\
\text { and community } \\
\text { resources }\end{array}$ & $31.2 \%$ & $14.5 \%$ & $42.4 \%$ & $74.6 \%$ \\
\hline $\begin{array}{l}\text { Released / } \\
\text { progressed }\end{array}$ & 20 of 58 & 20 of 36 & 8 of 13 & 27 of 29 \\
\hline $\begin{array}{l}\text { Odds ratio of } \\
\text { release/progression } \\
\text { relative to 'Recent } \\
\text { Unstable' offenders } \\
\left(\mathrm{R}^{2}=0.273\right)\end{array}$ & $\mathrm{n} / \mathrm{a}$ & $\begin{array}{c}2.4 \\
p=0.047\end{array}$ & $\begin{array}{c}3.0 \\
p=0.079\end{array}$ & $\begin{array}{c}25.6 \\
p<0.001\end{array}$ \\
\hline
\end{tabular}

$554 \quad \mathrm{BIC}=1398 ;$ Entropy=0.829 ('high') 